TARNOWSKIE STUDIA TEOLOGICZNE 37 (2018) NR 1-2, s. 111-127

http://dx.doi.org/10.15633/tst.3254

ks. Wojciech Witowski ${ }^{1}$

KATOLICKI UNIWERSYTET LUBELSKI JANA PAWŁA II

\title{
Proboszczowie kanonii w Biegonicach
}

Parafia pw. św. Wawrzyńca w Biegonicach (obecnie w Nowym Sączu-Biegonicach), jedna z najstarszych na Sądecczyźnie, została erygowana w 1269 roku przez biskupa krakowskiego, w wyniku fundacji św. Kingi ${ }^{2}$. W 2019 roku parafia będzie obchodzić jubileusz 750-lecia swego istnienia, jest to więc dobra okazja do opracowań na jej temat, także do prac historycznych, które przybliżają dzieje parafii. Przez prawie 350 lat, od roku 1448 do roku 1791, parafia była jedną z kanonii kapituły św. Małgorzaty w Nowym Sączu, dlatego wielu proboszczów było kanonikami tejże kapituły kolegiackiej.

Artykuł ma przedstawić sylwetki biegonickich proboszczów w latach istnienia kapituły, chociaż, jak zostanie to ukazane, nie wszyscy z nich byli kanonikami fundi Biegonice - stąd w tekście podział na proboszczów kanoników i proboszczów niebędących kanonikami. Prezentacja sylwetek biegonickich duszpasterzy zostanie poprzedzona krótkim zarysowaniem historii Kapituły Kolegiackiej w Nowym Sączu.

\section{Kanonia w Biegonicach}

4 października 1448 roku kard. Zbigniew Oleśnicki, ówczesny biskup krakowski, powołał do istnienia kolegiatę i kapitułę św. Małgorzaty w Nowym Sączu³.

\footnotetext{
1 Ks. Wojciech Witowski - kapłan diecezji tarnowskiej, student filologii klasycznej oraz doktorant z patrologii na Katolickim Uniwersytecie Lubelskim Jana Pawła II.

2 Por. B. Kumor, Archidiakonat Sądecki, opracowanie materiałów źródłowych do atlasu historycznego Kościoła w Polsce, „Archiwa, Biblioteki i Muzea Kościelne” 8-9 (1964), s. 295. Rok 1269 jako rok utworzenia parafii przyjmowany jest na podstawie różnych dokumentów, chociaż nie zachował się sam dokument erygujący parafię.

3 Por. J. Sygański, Nowy Sącz, jego dzieje i pamiątki dziejowe: szkic historyczny, Nowy Sącz 2011, s. 62; S. Salaterski, Kolegiata i kapituła św. Małgorzaty P.M. w Nowym Sączu (1448-1791), Tarnów 1997, s. 27-28.
} 
Kapituła kolegiacka wzorowana była na innych istniejących już w diecezji kapitułach. W jej skład wchodziło czterech prałatów - prepozyt, dziekan, archidiakon, kustosz oraz czterech kanoników, którzy posiadali swoje prebendy biegonicką, dąbrowską, chochorowską i niskowską. Do kapituły należało także kolegium ośmiu wikariuszy kolegiaty ${ }^{4}$. W późniejszych latach utworzono dodatkowe prałatury, ufundowano nowe kanonie, zmieniała się też liczba wikariuszy w tzw. kapitule mniejszej5.

Przy erygowaniu kapituły kard. Oleśnicki jednoznacznie określił, komu przysługuje prawo patronatu i prezenty na określone prałatury i kanonie. Sobie i kolejnym biskupom krakowskim zastrzegł prawo prezenty na prawie wszystkie prałatury oraz wszystkie kanonie. Wyjątkiem była godność kustosza, na którą prawo prezenty otrzymała rada miejska Nowego Sącza ${ }^{6}$. Po przedstawieniu odpowiedniego dokumentu kandydat mógł objąć swój urząd w kapitule podczas specjalnego obrzędu. Utrata miejsca w kapitule następowała na skutek śmierci, rezygnacji, przejścia na bardziej atrakcyjne beneficjum bądź na wniosek samej kapituły o usunięcie danego członka z jej grona ${ }^{7}$.

Kapituła Kolegiacka w Nowym Sączu istniała do 14 lipca 1791 roku, gdy została zniesiona na skutek reform kościelnych prowadzonych przez zaborczy rząd austriacki ${ }^{8}$.

Probostwo w Biegonicach wraz z utworzeniem kapituły stało się jedną z kanonii kapituły kolegiackiej. W związku z tym proboszczami biegonickimi mieli być członkowie kapituły, którzy byli mianowani kanonikami gremialnymi kanonii fundi Biegonice ${ }^{9}$. W zamyśle kard. Oleśnickiego, fundatora kapituły, stanowiska prałatów i kanoników mieli zajmować ludzie wykształceni, związani ze środowiskiem naukowym, dlatego też często wśród proboszczów biegonickich byli kapłani z tytułami naukowymi, jak doktor filozofii czy doktor praw ${ }^{10}$.

${ }^{4}$ Por. S. Salaterski, Kolegiata i kapituła..., s. 31.

5 Por. S. Salaterski, Kolegiata i kapituła..., s. 41.

${ }^{6}$ Por. S. Salaterski, Kolegiata i kapituła..., s. 46-48.

7 Por. S. Salaterski, Kolegiata i kapituła..., s. 57.

${ }^{8}$ Por. B. Kumor, Ustrój i organizacja Kościoła polskiego w okresie niewoli narodowej 17721918, Kraków 1980, s. 322. Reerygowanie nowosądeckiej kapituły kolegiackiej nastąpiło na podstawie dekretu bp. Józefa Życińskiego 8 grudnia 1996 roku, po ponad dwustu latach od jej skasowania. Por. R. Biel, Wczoraj i dziś Kapituły kolegiackiej w Nowym Sączu, Tarnów 2009, s. $159-160$.

${ }^{9}$ Por. B. Kumor, Archidiakonat Sądecki..., s. 116.

${ }^{10}$ Por. S. Salaterski, Kolegiata i kapituła..., s. 33. 
Urząd kanonika kapituły związany był nie tylko tytułem godności kościelnej (prałat, kanonik) i przywilejami w ubiorze kapłańskim (mucet, rokieta, mantolet), ale także z pobieraniem dziesięciny $\mathrm{z}$ wyznaczonej prebendy, czyli z określonym beneficjum (czerpanie dochodu) ${ }^{11}$. Prebenda w Biegonicach w chwili utworzenia kapituły przynosiła 12 grzywien uposażenia miesięcznie, co nie czyniło jej zbyt atrakcyjną w porównaniu z pozostałymi. Natomiast w roku 1776 wartość uposażenia prebendy biegonickiej wynosiła 400 florenów polskich, co czyniło ją już najbardziej atrakcyjną z prebend kanonickich ${ }^{12}$. Jednakże nie zawsze dziesięcina wypłacana była terminowo. Zdarzało się, że dochodziło do sporów między rolnikami a kanonikiem, albo nawet między proboszczem a roszczącym sobie prawo do kanonii innym duchownym ${ }^{13}$.

W kościołach kolegiackich fundowane też były altarie, które stanowiły rodzaj prebendy związanej ze sprawowaniem kultu przy konkretnym ołtarzu. W kolegiacie sądeckiej także fundowano altarie, które z czasem bywały włączane do poszczególnych kanonii. 25 stycznia 1472 roku ufundowana została altaria pw. św. Andrzeja. Fundatorem był Andrzej Trestka z Brzany, który zapisał na ten cel 6 grzywien rocznego dochodu. W tym samym roku fundacja została zatwierdzona. W 1725 roku biskup krakowski włączył tę altarię do kanonii biegonickiej ${ }^{14}$. W 1763 roku do kanonii biegonickiej włączono także altarię pw. Wszystkich Świętych, która wcześniej utrzymywana była wyłącznie $\mathrm{z}$ jałmużny ${ }^{15}$.

Wydawać się może, że bycie jedną z kanonii kapituły kolegiackiej, a co za tym idzie status parafii, której proboszczem jest kanonik, wiązało się z podniesieniem prestiżu samej parafii i lokalnej wspólnoty. Jednak w rzeczywistości, także w przypadku Biegonic, niosło to ze sobą pewne niedogodności. Za takie należy uznać: częste zmiany proboszczów, ich rezydowanie nie przy parafii, lecz przy kolegiacie, przedkładanie zainteresowania sprawami kapituły bądź środowiska naukowego, z którego proboszcz się wywodził, ponad troskę o parafię i parafian. Kanonicy, stając się prebendarzami w Biegonicach, mogli sami sprawować urząd proboszczowski, ale mogli też mieć kogoś w zastępstwie, kto administrowałby w ich imieniu parafią.

${ }^{11}$ Por. J. Sygański, Historya Nowego Sącza, t. 3: Zabytki dziejowe miasta, Lwów 1902, s. 91. Zob. także J. Sygański, Nowy Sącz, jego dzieje..., s. 62.

${ }_{12}$ Por. S. Salaterski, Kolegiata i kapituła..., s. 105.

${ }_{13}$ Por. S. Salaterski, Kolegiata i kapituła..., s. 100.

${ }^{14}$ Por. B. Kumor, Archidiakonat Sądecki..., s. 118.

15 Por. B. Kumor, Archidiakonat Sądecki..., s. 120. 


\section{Kanonicy kapituły sądeckiej proboszczami w Biegonicach}

Na podstawie katalogu członków kapituły stosunkowo łatwo ustalić listę proboszczów biegonickich, chociaż nie jest ona kompletna. Opracowania takiego katalogu podjął się historyk ks. dr Stanisław Salaterski ${ }^{16}$. Pomaga w tym także imienny spis proboszczów i administratorów od roku 1550, dostępny w archiwum parafialnym, jednak nie zawsze jest on zgodny z innymi źródłami ${ }^{17}$. Spis ten opiera się na księdze parafialnej: Elenchus Omnium Parochorum..., czyli na księdze zawierającej spis proboszczów z krótkimi adnotacjami na ich temat.

W 1470 roku jako kanonik sądecki kanonii biegonickiej wymieniany jest Mikołaj z Dobczyc ${ }^{18}$. Nie wiadomo, w jakich dokładnie latach pełnił urząd kanonika i proboszcza. Był magistrem sztuk wyzwolonych ${ }^{19}$. Jego dochód miał wynosić 16 grzywien w roku $1470^{20}$.

Z dokumentów wynika, że przed rokiem 1527 roku kanonię i probostwo biegonickie objął ks. Dobiesław Strzeżowski ${ }^{21}$. Beneficjum to posiadał do roku 1540, w którym zmarł ${ }^{22}$. Dochód kanonii miał wynosić wtedy 12 grzywien ${ }^{23}$.

Od 3 sierpnia 1541 roku kanonikiem kanonii biegonickiej i proboszczem w Biegonicach był ks. Marcin Dambrowski ${ }^{24}$. Wcześniej był on kapelanem kancelarii bp. Piotra Gamrata ${ }^{25}$. Nie wiadomo, do kiedy pełnił urząd kanonika i proboszcza w Biegonicach, jednak najpóźniej do roku 1550, ponieważ od tego roku proboszcz jest znany.

Kolejnym proboszczem, który jednocześnie był kanonikiem kapitulnym, był ks. dr Szymon Jaroszewski, który urząd proboszcza pełnił od 1638 do 1653 roku ${ }^{26}$. Był on kanonikiem i prepozytem nowosądeckim oraz spowiednikiem

${ }^{16}$ S. Salaterski, Katalog prałatów i kanoników kapituły św. Małgorzaty P.M. w Nowym Sączu (1448-1791), „Nasza Przeszłość” 8o (1993), s. 169-224.

${ }_{17}$ Por. Archiwum Parafii w Biegonicach [dalej: APB], Dokumenty różne, Wykaz księży proboszczów i administratorów parafii Biegonice od roku 1550.

${ }_{18}$ Por. J. Długosz, Liber Beneficiorum Dioecesis Cracoviensis, t. 1, Kraków 1863, s. 555.

19 Por. S. Salaterski, Katalog prałatów i kanoników..., s. 197.

${ }^{20}$ Por. B. Kumor, Dzieje diecezji krakowskiej do roku 1795, t. 3, Kraków 20oo, s. 271.

${ }^{21}$ Por. Archiwum Kurii Metropolitalnej w Krakowie [dalej: AKMK], Acta episcopalia $22(1538-1545)$, s. 14.

${ }^{22}$ Por. S. Salaterski, Katalog prałatów i kanoników..., s. 216.

${ }_{23}$ Por. B. Kumor, Dzieje diecezji krakowskiej..., s. 272.

${ }^{24}$ Por. AKMK, Acta episcopalia 19 (1541-1542), s. 211.

${ }_{25}$ Por. S. Salaterski, Katalog prałatów i kanoników..., s. 175.

${ }^{26}$ Por. S. Salaterski, Katalog prałatów i kanoników..., s. 185. 
klarysek ze Starego Sącza ${ }^{27}$. Zapamiętany został jako zasłużony i świątobliwy kapłan. Był doktorem obojga praw. Zmarł w Nowym Sączu ${ }^{28}$. Prepozytem kapituły nowosądeckiej był od roku $164 \mathrm{O}^{29}$. Od tego też roku był równocześnie proboszczem w Biegonicach i proboszczem kolegiaty w Nowym Sączu ${ }^{30}$. W czasie jego proboszczowania, w roku 1647, przystąpiono do budowy nowego, trzeciego kościoła parafialnego oraz odnowiono dawną fundację św. Kingi ${ }^{31}$. Ksiądz Jaroszewski był także zasłużony dla Starego Sącza, gdyż był opiekunem szpitala dla ubogich oraz, jako miłośnik muzyki, przyczynił się dla rozwoju muzyki w tym mieście ${ }^{32}$. W swoim testamencie zostawił zapisy na rzecz starosądeckiego klasztoru klarysek oraz nowosądeckiej kapituły ${ }^{33}$.

Od 1653 do 1670 roku proboszczem w Biegonicach był ks. dr Adam Bydłoniewicz (Bydlewicz), pochodzący ze Starego Sącza ${ }^{34}$. On rozpoczął pisanie kroniki parafialnej oraz uporządkował sprawy gospodarcze i księgi metrykalne w archiwum parafialnym. Był absolwentem studiów z filozofii oraz sztuk wyzwolonych na Akademii Krakowskiej ${ }^{35}$. Przed proboszczowaniem w Biegonicach był proboszczem w Piwnicznej, w latach 1642-1653. Uczestniczył aktywnie w działaniach kapituły sądeckiej, w której był najpierw kanonikiem, a później prałatem kustoszem ${ }^{36}$. Adnotacja na marginesie spisu proboszczów sugeruje, że przez parafian biegonickich został zapamiętany jako bardzo gorliwy i uczynny duszpasterz ${ }^{37}$.

Podczas wizytacji bp. Andrzeja Trzebickiego w 1659 roku ks. Bydłoniewicz miał wnieść skargę na proboszcza ze Starego Sącza, któremu na czas najazdu

${ }^{27}$ Por. Archiwum Parafii św. Małgorzaty w Nowym Sączu [dalej: APNs], Acta venerabilis Capituli praelatorum Ecclesiae Collegiatae Sandecensis ab anno salutis 1638 caepta, s. 9, 17 .

${ }_{28}$ Por. APB, Dokumenty różne, Wykaz księży proboszczów i administratorów parafii Biegonice od roku 1550.

${ }^{29}$ Por. J. Kracik, Kontrreformacja i katolicka reforma, w: Dzieje miasta Nowego Sącza, t. 1, red. F. Kiryk, Warszawa-Kraków 1992, s. 417.

$3^{\circ}$ Por. W. Bazielich, Materiały do historii szpitala, kościoła i prepozytury św. Krzyża w Starym Sączu, „Nasza Przeszłość” 14 (1961), s. 227.

${ }_{31}$ Por. A PB, Dokumenty różne, Historia parafii spisana przez ks. Andrzeja Niemca (rkps).

${ }^{32}$ Por. S. Fyda, Kronika Ochotniczej Straży Pożarnej w Biegonicach (rkps).

${ }^{33}$ Por. W. Bazielich, Materiały do historii..., s. 226-227.

${ }^{34}$ Por. S. Salaterski, Katalog prałatów i kanoników..., s. 174.

35 Por. W. Bazielich, Materiały do historii..., s. 228.

${ }^{36}$ Por. APNS, Acta venerabilis Capituli praelatorum Ecclesiae Collegiatae Sandecensis ab anno salutis 1638 caepta, s. 20, 32, 55 .

37 Por. APB, Dokumenty różne, Wykaz księży proboszczów i administratorów parafii Biegonice od roku 1550. 
szwedzkiego powierzył na przechowanie monstrancję. Monstrancja została zrabowana, a proboszcz starosądecki nie chciał zwrócić jej wartości. Biskup nakazał wynagrodzić parafię biegonicką plebanowi Kownackiemu ze Starego $\mathrm{Sącza}^{38}$. W roku 1660 ks. Bydłoniewicz ufundował do kościoła rzeźbione kamienne baptysterium, jeden z cenniejszych zabytków znajdujących się obecnie w kościele ${ }^{39}$. Jako proboszcz biegonicki był również spowiednikiem sióstr klarysek, kustoszem kolegiaty nowosądeckiej oraz prepozytem szpitali dla ubogich w Nowym i Starym Sączu ${ }^{40}$. Z powodu wielu obowiązków wynikających z pracy naukowej oraz kapitulnej, w czasie pełnienia przez niego urzędu proboszcza, dla parafii został powołany administrator w latach $1663-1669^{41}$. Zmarł 23 maja 1670 roku. Pochowany został w kolegiackie sądeckiej. Uważany był za najwybitniejszego prepozyta szpitala w Starym Sączu. W testamencie zostawił zapis na rzecz parafii w Biegonicach, kapituły sądeckiej oraz starosądeckiego szpitala. W nim też opisał swoje cudowne uzdrowienie, które miało się dokonać za przyczyną bł. Kingi ${ }^{42}$. Miał posiadać dużą bibliotekę w swoim mieszkaniu ${ }^{43}$.

Od roku 1689 funkcję proboszcza pełnił ks. Jakub Żelazowski ${ }^{44}$. Był wykształconym kapłanem, studiował na Akademii Krakowskiej, gdzie uzyskał doktorat $\mathrm{z}$ filozofii oraz doktorat $\mathrm{praw}^{45}$. Nim został kanonikiem sądeckim, piastował godności w kapitułach bobowskiej oraz tarnowskiej ${ }^{46}$. W 1689 roku został prałatem archidiakonem kapituły sądeckiej i w tym czasie objął probostwo w Biegonicach. Był protonotariuszem apostolskim. Zmarł w roku $1693^{47}$.

${ }^{38}$ Por. W. Bazielich, Parafialni proboszczowie starosądeccy, „Nasza Przeszłość” 9 (1959), s. $109-110$.

39 Por. А РB, Dokumenty różne, Historia parafii spisana przez ks. Andrzeja Niemca (rkps).

${ }^{40}$ Por. AKMK, Acta episcopalia 59 (1658-1659), s. 300.

${ }^{41}$ Por. APB, Dokumenty różne, Wykaz księży proboszczów i administratorów parafii Biegonice od roku 1550. Administratorem tym był ks. Stanisław Piczek, który po awansie ks. Bydłoniewicza został kanonikiem kanonii biegonickiej. Por. APNS, Acta venerabilis Capituli praelatorum Ecclesiae Collegiatae Sandecensis ab anno salutis 1638 caepta, s. 42, 44, 47, 49, 51, 53, 55; oraz S. Salaterski, Katalog prałatów i kanoników..., s. 205.

${ }^{42}$ Por. W. Bazielich, Materiaty do historii..., s. 229.

${ }^{43}$ Por. T. Opas, Zabudowa i mieszkańcy, w: Dzieje miasta Nowego Sacza, t. 1, s. 592.

${ }_{44}$ Tego proboszcza brak w wykazie parafialnym, mówią o nim jednak inne źródła. Por. S. Salaterski, Katalog prałatów i kanoników..., s. 224.

45 Por. АКмК, Acta episcopalia 72 (1692-1693), s. 397.

${ }^{46}$ Por. F. Herzig, Katedra, niegdyś kolegiata $w$ Tarnowie, Tarnów 1900, s. 58.

47 Por. APNS, Acta venerabilis Capituli praelatorum Ecclesiae Collegiatae Sandecensis ab anno salutis 1638 caepta, s. 107, 108. 
Okres od 1700 do 1775 roku to czas upadku moralnego i dyscyplinarnego społeczności („czasy saskie”). W tym czasie następowały częste zmiany proboszczów. Duszpasterze albo rezygnowali z pracy z powodu zniechęcenia, albo tracili siły i zdrowie, albo dostosowywali się do panującego ducha. Nie były to czasy sprzyjające prowadzeniu duszpasterstwa ${ }^{48}$.

W latach 1711-1728 urząd proboszcza parafii pełnił ks. Tomasz Majowski ${ }^{49}$. Studiował on na Akademii Krakowskiej nauki wyzwolone i filozofię, z której miał uzyskać doktorat. W kapitule sądeckiej był kanonikiem fundi Biegonice oraz fundi Fabiankowski, od 1721 roku pełnił funkcje dziekana kapituły, a od roku 1722 był oficjałem okręgowym w Nowym Sączu ${ }^{50}$. Był spowiednikiem sióstr klarysek. Zmarł w roku $1732^{51}$.

Następcą ks. Majowskiego został ks. Kazimierz Stanisław Pałaszowski ${ }^{52}$. Parafią kierował od 1732 do 1738 roku $^{53}$. Urodził się 28 lutego 1692 roku. Po studiach na Akademii Krakowskiej uzyskał magisterium sztuk wyzwolonych oraz doktorat $\mathrm{z}$ filozofii, a w późniejszych latach także doktorat $\mathrm{z}$ teologii ${ }^{54}$. Po studiach prowadził wykłady oraz uczył w różnych szkołach. Był dziekanem i rektorem Akademii. Działalność naukową prowadził zarówno przed

${ }^{48}$ Por. APB, Dokumenty różne, Historia parafii spisana przez ks. Andrzeja Niemca (rkps).

49 Por. APB, Dokumenty różne, Wykaz księży proboszczów i administratorów parafii Biegonice od roku 1550.

${ }^{50}$ Por. AKMK, Acta episcopalia 77 (1714-1719), s. 634; 78 (1720-1723), s. 129.

${ }_{51}$ Por. S. Salaterski, Katalog prałatów i kanoników..., s. 194.

${ }^{52}$ Por. S. Salaterski, Katalog prałatów i kanoników..., s. 202-203. Ksiądz Salaterski wśród pełnionych urzędów nie wymienia probostwa ani kanonii biegonickiej, jednak nazwisko i lata życia wskazują na tego duchownego. W tym samym roku (1732), kanonikiem fundi Biegonice miał zostać ks. Wojciech Wagurski, jednak zrezygnował on z funkcji przed jej objęciem. Por. AKMK, Acta episcopalia 81 (1731-1732), s. 163 oraz S. Salaterski, Katalog prałatów i kanoników..., s. 219. Także w roku 1732 beneficjum kanonii biegonickiej miał objąć ks. Michał Awedyk, który kanonię tę posiadał do swej śmierci w roku 1760. Był on doktorem filozofii, nauk wyzwolonych oraz prawa i teologii. Był także doktorem medycyny. W 1744 roku został kanonikiem w Gnieźnie, a w roku 1749 w Łowiczu. Był sekretarzem króla Augusta III Sasa. Łączył wiele beneficjów kościelnych. Por. S. Salaterski, Katalog prałatów i kanoników..., s. 170-171. Szerzej zob. J. Lachs, Awedyk Michał, w: Polski słownik biograficzny, t. 1, Kraków 1935, s. 190; W. Murawiec, Awedyk Michał, w: Słownik polskich teologów katolickich, t. 1, red. H. Wyczawski, Warszawa 1981, s. $80-81$.

${ }^{53}$ Por. APB, Dokumenty różne, Wykaz księży proboszczów i administratorów parafii Biegonice od roku 1550.

${ }^{54}$ Por. W Baczkowska, Pałaszowski Kazimierz Stanisław, w: Polski słownik biograficzny, t. 25, Kraków 1980, s. 203-204. 
przyjęciem święceń, jak i po ich przyjęciu ${ }^{55}$. Święcenia przyjął przed rokiem 1727 i od tego czasu pełnił wiele funkcji kościelnych, w tym urząd proboszcza w Biegonicach, był również kanonikiem, a później prałatem kanclerzem w kapitule sądeckiej ${ }^{56}$. Po roku 1738 był proboszczem w Krakowie oraz pełnił funkcje w kapitule katedralnej w stolicy diecezji ${ }^{57}$. Zmarł w roku 1758.

W wykazie proboszczów biegonickich, z dopiskiem "nielegalny proboszcz”, widnieje wspomniany ks. Wojciech Mroziński, który miał pełnić urząd w latach 1749-1761. Okres ten pokrywa się z czasem proboszczowania przez ks. Jana Sitowskiego (proboszcza spoza kapituły). Pomiędzy proboszczem ks. Sitowskim a ks. Mrozińskim istniał spór o pobieranie dziesięciny z kanonii biegonickiej. Prawdopodobnie obaj byli prezentowani na to stanowisko, jednak ks. Sitowski faktycznie pełnił obowiązki proboszcza ${ }^{58}$. Przy ks. Mrozińskim w spisie proboszczów widnieje informacja, że był nerwowym i interesownym człowiekiem ${ }^{59}$. Wojciech Mroziński urodził się w 1717 roku, studiował na Akademii Krakowskiej. Od 1775 roku był proboszczem w Łącku, wcześniej - w nieokreślonych latach - miał być proboszczem w Siedlcach i w Biegonicach ${ }^{60}$. W kapitule sądeckiej był najpierw kanonikiem honorowym, później kanonikiem gremialnym fundi Dąbrówka, od 1774 roku dziekanem kapituły, a od 1781 roku oficjałem sądeckim ${ }^{61}$.

W Biegonicach przez dwadzieścia lat, od 1775 do 1795 roku, pracował jako proboszcz ks. dr Franciszek Pasiewicz ${ }^{62}$. Urodził się w 1715 roku w Starym Sączu. Gimnazjum ukończył w Podolińcu, a następnie studiował w Krakowie, gdzie uzyskał doktorat z teologii. Święcenia kapłańskie przyjął około roku 1740 w Krakowie. Po święceniach pełnił posługę kapelana szpitala w Starym Sączu. Prawdopodobnie od 1769 roku był proboszczem w Barcicach. W sierpniu 1775

55 Por. B. Natoński, Pałaszowski Kazimierz, w: Słownik polskich teologów katolickich, t. 3, red. H. Wyczawski, Warszawa 1982, s. 294-296.

${ }^{56}$ Por. APNS, Acta venerabilis Capituli praelatorum Ecclesiae Collegiatae Sandecensis ab anno salutis 1638 caepta, s. 220, 221, 240, 241.

57 Por. AкMK, Acta episcopalia 80 (1728-1730), s. 168.

${ }_{58}$ Por. S. Salaterski, Kolegiata i kapituła..., s. 100.

59 Por. АРB, Dokumenty różne, Wykaz księży proboszczów i administratorów parafii Biegonice od roku 1550.

${ }^{60}$ Por. S. Salaterski, Katalog prałatów i kanoników..., s. 198.

${ }_{61}$ Por. AкMK, Acta epispoalia 100 (1774-1775), s. 21, 23.

${ }^{62}$ Por. APB, Dokumenty różne, Wykaz księży proboszczów i administratorów parafii Biegonice od roku 1550. 
roku został kanonikiem honorowym kolegiaty nowosądeckiej ${ }^{63} .14$ września 1775 roku został proboszczem w Biegonicach, rezygnując z poprzedniej parafii. Został zapamiętany przez parafian jako kapłan zasłużony w parafii i poza nią ${ }^{64}$. W kapitule nowosądeckiej uczestniczył tylko w jednym posiedzeniu, podczas którego został instalowany jako kanonik ${ }^{65}$. Ksiądz Salaterski nie precyzuje, czy oprócz bycia kanonikiem honorowym został kanonikiem fundi Biegonice ${ }^{66}$. Gorliwie kontynuował dzieło swojego poprzednika, ks. Sitowskiego, zmierzające do naprawy upadłej moralności i obyczajów. Za jego czasów „duch w parafii się obudził i ludzie skierowali się więcej do Boga" ${ }^{\text {67. }}$. Była to działalność podejmowana ogólnie w całej Polsce, aby odnowić pobożność i religijność po „czasach saskich”. W czasie pełnienia przez niego urzędu proboszcza, na skutek dekretu austriackiego zaborcy, kościół parafialny został pozbawiony wszelkich kosztowności ${ }^{68}$. Zmarł w styczniu 1795 roku w Biegonicach ${ }^{69}$.

Ksiądz Franciszek Pasiewicz był ostatnim proboszczem biegonickim - kanonikiem nowosądeckim w tamtych czasach, ponieważ 14 lipca 1791 roku kapituła kolegiacka św. Małgorzaty w Nowym Sączu została zniesiona, na skutek reform kościelnych prowadzonych przez zaborczy rząd austriacki ${ }^{{ }^{\circ}}$.

\section{Proboszczowie spoza kapituły}

Dostępne źródła nie pozwalają w każdym przypadku określić, czy wszyscy proboszczowie byli kanonikami sądeckimi prebendy biegonickiej. Z powodu wątpliwości oraz braku ich nazwisk w katalogu ks. Salaterskiego, trzeba uważać ich za proboszczów spoza kapituły.

Od 1550 do 1568 roku parafią w Biegonicach kierował ks. Hadrian de Costen Habdański, pierwszy proboszcz wymieniony w parafialnym spisie proboszczów

\footnotetext{
${ }^{63}$ Por. S. Salaterski, Katalog prałatów i kanoników..., s. 203.

${ }^{64}$ Por. APB, Dokumenty różne, Wykaz księży proboszczów i administratorów parafii Biegonice od roku 1550.

${ }^{65}$ Por. APNS, Acta venerabilis Capituli praelatorum Ecclesiae Collegiatae Sandecensis ab anno salutis 1638 caepta, s. 421.

${ }^{66}$ Według ks. Bolesława Kumora w 1776 roku kanonikiem fundi Biegonice był ks. Marcin Reczkowski, pobierający 400 florenów dochodu. Por. B. Kumor, Dzieje diecezji krakowskiej..., s. 275.

${ }^{67}$ APB, Dokumenty różne, Historia parafii spisana przez ks. Andrzeja Niemca (rkps).

${ }^{68}$ Por. A PB, Dokumenty różne, Historia parafii spisana przez ks. Andrzeja Niemca (rkps).

${ }^{69}$ Por. A. Nowak, Słownik biograficzny kapłanów Diecezji Tarnowskiej 1786-1985, t. 3, K-P, Tarnów 2001, s. 291.

${ }^{70}$ Por. B. Kumor. Ustrój i organizacja Kościoła..., s. 322.
} 
i administratorów ${ }^{71}$. Z informacji znajdującej się obok jego nazwiska wynika, że był bardzo zasłużonym dla parafii proboszczem, oddanym duszpasterstwu i wiernym. Zmarł w Biegonicach, gdzie prawdopodobnie też został pochowa$n^{72}$. W czasie pełnienia przez niego urzędu proboszcza, w roku 1553, zakupiono do kościoła parafialnego trzeci dzwon ${ }^{73}$. Od pierwszej niedzieli czerwca 1553 roku ks. Habdański był prepozytem szpitala dla ubogich w Starym Sączu ${ }^{74}$. Widać więc, że jego działalność nie była związana jedynie z parafią, ale sięgała dalej. Kapłan ten nie został wymieniony w katalogu kanoników sądeckich u ks. Salaterskiego.

Kolejnym proboszczem biegonickim był ks. Stanisław Wąsowicz. Urząd proboszcza pełnił w latach $1574^{-1590}$. Został zapamiętany jako zasłużony dla parafii duszpasterz. Od 14 września 1584 roku był prepozytem szpitala w Starym Sączu. On rozpoczął prowadzenie szpitalnego rejestru, zawierającego spis prepozytów oraz ważniejsze wydarzenia i wydatki związane ze szpitalem. Posiadał tytuł bakalarza sztuk wyzwolonych ${ }^{75}$. Był także spowiednikiem sióstr klarysek w Starym Sączu. Zmarł w Nowym Sączu w roku 1590 ${ }^{76}$. W Elenchusie przy nazwisku tego proboszcza widnieje dopisek Canonicus Colegiatae Neosandecensi, ale nie został on wymieniony w katalogu kanoników ks. Salaterskiego, nie ma więc pewności, czy był członkiem kapituły ${ }^{77}$.

Jego następcą został ks. Andrzej Wagrocki, proboszcz od 1591 do 1608 roku $^{78}$. Zmarł w Nowym Sączu 14 marca 1608 roku ${ }^{79}$. Również o nim zapiski w księdze

${ }^{71}$ Por. APB, Dokumenty różne, Wykaz księży proboszczów i administratorów parafii Biegonice od roku 1550.

${ }^{72}$ Por. APB, Dokumenty różne, Wykaz księży proboszczów i administratorów parafii Biegonice od roku 1550.

73 Por. A PB, Dokumenty różne, Wykaz ważniejszych wydarzeń z historii parafii [b.d.].

74 Por. W. Bazielich, Materiały do historii..., s. 213.

75 W. Bazielich, Materiały do historii..., s. 216-217.

${ }^{76}$ Por. A PB, Dokumenty różne, Wykaz księży proboszczów i administratorów parafii Biegonice od roku 1550.

77 U ks. Salaterskiego wymieniony jest inny kanonik o nazwisku Wąsowicz - Mikołaj, był on jednak proboszczem w Starym Sączu, a lata życia nie pozwalają utożsamiać go z proboszczem biegonickim. Por. S. Salaterski, Katalog prałatów i kanoników..., s. 219. Według Bazielicha Mikołaj proboszcz starosądecki był bratem proboszcza z Biegonic. Por. W. Bazielich, Materiaty do historii..., s. 218.

${ }^{78}$ Por. APB, Dokumenty różne, Wykaz księży proboszczów i administratorów parafii Biegonice od roku 1550.

79 Por. Акмк, Acta visitationis nr 65, k. 98; nr 21, s. 196; także: J. Szymański, Kapituła kolegiacka $w$ Wojniczu 1465-1786, Lublin 1962, s. 195 (tam jego nazwisko pisane jest Wagrowski 
parafialnej mówią, że był kanonikiem kolegiaty św. Małgorzaty oraz oficjałem nowosądeckim ${ }^{80}$. Jednak tego proboszcza także brak w katalogu kanoników ks. Salaterskiego, a w okresie jego proboszczowania wymieniani są inni kanonicy, którzy nie byli proboszczami w Biegonicach ${ }^{81}$. W czasie pełnienia przez niego posługi proboszcza parafię wizytował biskup krakowski, kard. Jerzy Radziwiłł. Według dekretu wizytacyjnego stan parafii, jak i praca proboszcza zostały ocenione pomyślnie ${ }^{82}$.

Kolejnym proboszczem biegonickim był ks. Stanisław Wcianeczek. Urodził się w roku 1574 w Starym Sączu. Urząd proboszcza pełnił od 1608 do 1624 roku ${ }^{83}$. Przez ówczesną ludność został zapamiętany jako kapłan bardzo zasłużony dla samej parafii, jak i dla Sądecczyzny w ogóle. Był proboszczem w Piwnicznej, prebendarzem Krzyża Świętego w Starym Sączu ${ }^{84}$ i spowiednikiem sióstr klarysek w Starym Sączu. Od 1608 roku pracował w Biegonicach, gdzie z zaangażowaniem szerzył kult św. Kingi oraz był inicjatorem budowy kościółka Opatrzności Bożej i św. Sebastiana na Podoleńcu. W roku 1622 w czasie epidemii „czarnej śmierci” ks. Wcianeczek bardzo poświęcał się, spowiadając i przygotowując chorych na śmierć. Proboszcz szerzył także kult św. Sebastiana - patrona od zarazy, dlatego też orędował za budową świątyni poświęconej temu świętemu. „Tak zapisy, jak i miejscowa tradycja podają, że dopóki stał ten kościółek i dopóki istniał w nim kult św. Sebastiana, żadna

i wymieniany jest jako kanonik wojnicki od 1596 do 1608 roku oraz równocześnie proboszcz biegonicki).

${ }^{80}$ Jako oficjała nowosądeckiego wymienia go ks. Kumor w spisie wikariuszy kapituły nowosądeckiej z roku 1597. Por. B. Kumor, Dzieje diecezji krakowskiej..., s. 292-293.

${ }^{81}$ Według ks. Salaterskiego w okresie proboszczowania przez ks. Andrzeja Wagrockiego miały miejsca inne nominacje na kanonie biegonicką. W 1595 roku kanonikiem fundi Biegonice miał zostać Zygmunt Rościszewski, który nie objął beneficjum z powodu wyjazdu do Rzymu i późniejszej nominacji w kapitule krakowskiej (szerzej zob. L. Łętowski, Katalog biskupów, prałatów i kanoników krakowskich, t. 4, Kraków 1853, s. 10). W roku 1596 kanonię biegonicką miał objąć Andrzej Jagła, który szybko miał z niej zrezygnować. Por. S. Salaterski, Katalog prałatów i kanoników..., s. 182, 210. Także według ks. Kumora w 1597 kanonikiem fundi Biegonice był wspomniany Andrzej Jagla (Włoch). Por. B. Kumor, Dzieje diecezji krakowskiej..., s. 272.

${ }^{82}$ Por. A PB, Dokumenty różne, Historia parafii spisana przez ks. Andrzeja Niemca (rkps).

${ }_{33}$ Por. APB, Dokumenty różne, Wykaz księży proboszczów i administratorów parafii Biegonice od roku 1550.

${ }^{84}$ O pełnieniu funkcji prepozyta szpitalnego w Starym Sączu świadczą zapiski parafialne, jednak ks. Stanisław Wcianeczek nie jest wymieniony w cytowanym wcześniej artykule Bazielicha. Od 1608 do 1620 roku prebendarzem kościoła szpitalnego miał być ks. Kacper Basilich. Por. W. Bazielich, Materiaty do historii..., s. 222-224. 
z licznych późniejszych zaraz nie nawiedzała Biegonic, ani tych rodzin, które miały nabożeństwo do św. Sebastiana, co przypisywano zasługom tegoż świę-

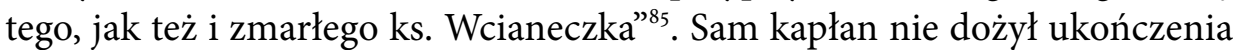
rozpoczętej przez siebie budowy, zmarł w Biegonicach w 1624 roku $^{86}$. Według dopisku umieszczonego na spisie proboszczów, „zmarł w opinii świętości”.

Pewnych informacji dotyczących życia ks. Wcianeczka dostarcza list ks. Karola Szymaszka adresowany do prof. Wiktora Bazielicha. Według tego listu zaangażowanie duszpasterskie ks. Wcianeczka oraz jego poświęcenie w czasie epidemii zostało oddane na obrazie wotywnym znajdującym się w nowosądeckiej kolegiacie. Obraz ten przedstawia ks. Stanisława jako orędownika Sądecczyzny, Ojczyzny i Kościoła. Malowidło zostało ufundowane w roku 1624, jako pośmiertne wotum wdzięczności, przez przyjaciół księdza i podopiecznych z terenu Sądecczyzny ${ }^{87}$. Obraz miał namalować mistrz Jan Alexander Trycjusz ${ }^{88}$. Przedstawienie na obrazie znajdującym się w kolegiacie sądeckiej może sugerować, że kapłan ten był członkiem kapituły, chociażby $z$ racji bycia proboszczem biegonickim, jednak nie jest wymieniony w spisie kanoników ${ }^{89}$. W Elenchusie przy jego nazwisku widnieje dopisek Canonicus Cracoviensis, czyli kanonik krakowski.

Kolejnym proboszczem w Biegonicach został ks. Sebastian Zagrowski (Zagrodzki), pochodzący z Biecza. Urząd proboszcza pełnił w latach 1624-

${ }_{5}^{85}$ Por. APB, Dokumenty różne, List ks. Karola Szymaszka, administratora w Biegonicach do prof. Wiktora Bazielicha, dotyczący ks. Stanisława Wcianeczka [Odbitka ze zbiorów Archiwum Państwowego w Nowym Sączu; Zbiór sygn. vi 6].

${ }^{86}$ Por. APB, Dokumenty różne, Wykaz księży proboszczów i administratorów parafii Biegonice od roku 1550.

${ }^{87}$ Por. APB, Dokumenty różne, List ks. Karola Szymaszka, administratora w Biegonicach do prof. Wiktora Bazielicha, dotyczący ks. Stanisława Wcianeczka [Odbitka ze zbiorów Archiwum Państwowego w Nowym Sączu; Zbiór sygn. vi 6].

${ }^{88}$ Por. А PB, Dokumenty różne, Wykaz księży proboszczów i administratorów parafii Biegonice od roku 1550.

${ }^{89}$ Według ks. Salaterskiego od 1611 roku kanonikiem kanonii biegonickiej był ks. Jakub Janidłowicz (zapewne do śmierci, czyli do roku 1619). Był on doktorem obojga praw i liczne obowiązki w diecezji i poza nią, powodowały, że nie bywał w Nowym Sączu, ani tym bardziej nie spełniał obowiązków proboszcza w Biegonicach. Por. S. Salaterski, Katalog prałatów i kanoników..., s. 182-183. Więcej o ks. Janidłowiczu por. J. Bieniarzówna, Janidło Jakub, w: Polski słownik biograficzny, t. 10, Kraków 1962-1964, s. 512. 15 czerwca 1620 roku kanonikiem fundi Biegonice miał zostać Mikołaj Porowski, wymieniany jako kanonik wojnicki, brak jednak potwierdzenia, by przyjął ten urząd lub spełniał obowiązki proboszcza w Biegonicach. Por. S. Salaterski, Katalog prałatów i kanoników..., s. 206. Szerzej o ks. Mikołaju Porowskim, jako kanoniku wojnickim, zob. J. Szymański, Kapituła kolegiacka w Wojniczu 1465-1786, s. 184. 
$1638^{90}$. Za jego proboszczowania ukończono budowę kościółka na Podoleńcu, rozpoczętą przez poprzedniego proboszcza. Był spowiednikiem sióstr klarysek w Starym Sączu ${ }^{91}$. Prawdopodobnie był dobrze wykształconym człowiekiem, o czym może świadczyć pozostawiony w archiwum fragment aktu fundacyjnego napisanego $\mathrm{z}$ wielkim zacięciem humanistycznym ${ }^{92}$. Nie został on wymieniony w katalogu kanoników sądeckich, chociaż w Elenchusie przy jego nazwisku znajduje się dopisek Canonicus Colegiatae.

Proboszczem biegonickim był także ks. Sebastian Wachowicz. Parafią kierował od 1670 do 1680 roku. Ukończył studia filozoficzne ${ }^{93}$. Nie został wymieniony w katalogu kanoników sądeckich, nie ma także o nim więcej informacji. Jego następcą był ks. Mikołaj Woszczyński. Proboszczem w Biegonicach był od 1681 do 1689 roku ${ }^{94}$. Według zapisków w Elenchusie miał być dziekanem kapituły kolegiackiej (Decanus Colegiatae) i spowiednikiem sióstr ze Starego Sącza. Jego nazwisko nie jest jednak wymienione w katalogu ks. Salaterskiego.

Przez kilka lat, od 1738 do 1744 roku, proboszczem biegonickim był ks. Karol Dierżkowski. Został zapamiętany jako zasłużony dla parafii duszpasterz. Pełnił również urząd proboszcza w Tyliczu ${ }^{95}$. Był spowiednikiem klarysek w Starym Sączu. Nie jest wymieniony w katalogu kanoników sądeckich ks. Salaterskiego. W Elenchusie przy nazwisku ks. Dierżkowskiego znajduje się przekreślona uwaga Cacnonicus colegiatus, a obok dopisano słowa: factus Canonicus Cracoviae, co sugeruje, że był kanonikiem katedralnym lub jednej z kapituł w Krakowie.

W latach 1744-1775 proboszczem biegonickim był ks. Jan Sitowski. Był to kapłan bardzo dzielny i gorliwy, lecz zapamiętano go także jako nieco popędliwego i wojowniczego, czym przysporzył sobie wielu niepotrzebnych przykrości

$9^{\circ}$ Por. APB, Dokumenty różne, Wykaz księży proboszczów i administratorów parafii Biegonice od roku 1550.

${ }_{91}$ Por. APB, Dokumenty różne, Historia parafii spisana przez ks. Andrzeja Niemca (rkps).

${ }_{92}$ Por. АРB, Dokumenty różne, Akt fundacyjny ks. Sebastiana Zagrodzkiego, plebana biegonickiego, na rzecz Bractwa Różańcowego przy ołtarzu Zwiastowania Najświętszej Maryi Panny w farze bieckiej, z dnia 6.01.1632. [fragment].

${ }^{93}$ Por. APB, Dokumenty różne, Wykaz księży proboszczów i administratorów parafii Biegonice od roku 1550.

${ }^{94}$ Por. APB, Dokumenty różne, Wykaz księży proboszczów i administratorów parafii Biegonice od roku 1550. Według spisu parafialnego miał pełnić urząd proboszcza do roku 1711, jednak od roku 1689 w źródłach wymieniany jest już inny proboszcz.

95 Por. APB, Dokumenty różne, Wykaz księży proboszczów i administratorów parafii Biegonice od roku 1550. Według dopisku w Elenchusie proboszczem w Tyliczu miałby być w latach $1707-1743$. 
i nieprzyjemności zarówno ze strony miejscowych, jak i poza miejscowych czynników. Jako proboszcz był wielce zasłużony dla parafii, duszpasterstwa, kościoła i całego beneficjum kościelnego ${ }^{96} .8$ czerwca 1775 roku na plebanii w Biegonicach został zamordowany skrytobójczo przez swoich wrogów ${ }^{97}$. Ksiądz Andrzej Niemiec pisze, że ks. Sitowski, ostatni pleban niechlubnego okresu w historii Biegonic („czasów saskich”), przez trzydzieści lat swojego proboszczowania wiele wycierpiał, ale też podjął wiele trudów, by usunąć panoszące się zło z parafii ${ }^{98}$. Nie jest wymieniany w katalogu kanoników sądeckich, na pewno nie był kanonikiem fundi Biegonice, bo to beneficjum do śmierci posiadał ks. Michał Awedyk ${ }^{99}$. Nazwisko ks. Sitowskiego wspominane jest przy okazji sporu z innym kanonikiem sądeckim, ks. Wojciechem Mrozińskim.

Jak widać, dostępne źródła nie pozwalają jednoznacznie określić nawet dokładnego spisu proboszczów z precyzyjnym podaniem czasu, w którym mieliby pełnić urząd proboszczowski. Niejednokrotnie wynika to z kumulowania beneficjów kościelnych przez duchownych, co prowadziło do pełnienia niektórych funkcji przez zastępcę. W omawianym okresie dostrzega się przerwy w urzędowaniu pomiędzy kolejnymi proboszczami. Czasami spowodowane jest to wakatem na stanowisku proboszcza i powołaniem tymczasowego administratora (administratorów nie uwzględniono w tym opracowaniu), a czasem wynika to $\mathrm{z}$ trudności w ustaleniu dat granicznych proboszczowania przez kolejnych duszpasterzy.

W czasie przygotowywania powyższego opracowania udało się ustalić, dokładniejszą niż była dostępna w archiwum parafialnym, listę proboszczów biegonickich, chociaż wciąż pozostaje ona niepełna. Konfrontacja różnych źródeł pozwala stwierdzić, że w latach istnienia kapituły w Nowym Sączu niektórzy

${ }^{96}$ Por. АРB, Dokumenty różne, Wykaz księży proboszczów i administratorów parafii Biegonice od roku 1550.

${ }^{97}$ Por. S. Fyda, Kronika Ochotniczej Straży Pożarnej w Biegonicach (rkps).

${ }_{98}$ Por. A РB, Dokumenty różne, Historia parafii spisana przez ks. Andrzeja Niemca (rkps).

99 Por. S. Salaterski, Katalog prałatów i kanoników..., s. 171. Po śmierci ks. Michała Awedyka, w 1760 roku kanonię fundi Biegonice miał objąć (przez pełnomocnika) ks. Marcin Mikołaj Troynarski, doktor obojga praw i proboszcz w Koprzywnicy. Posiadał on beneficja również w diecezji włocławskiej i rzadko bywał w Nowym Sączu. Zmarł po 1782 roku, nie wiadomo, do kiedy posiadał kanonię biegonicką. Por. S. Salaterski, Katalog prałatów i kanoników..., s. 218-219. Według źródeł ks. Marcin Troynarski częściej przedstawiał usprawiedliwienie nieobecności w posiedzeniach kapituły, niż w nich uczestniczył. Por. AKMK, Acta episcopalia 98 (1759-1768), s. 34 oraz APNS, Acta venerabilis Capituli praelatorum Ecclesiae Collegiatae Sandecensis ab anno salutis 1638 caepta, s. $315,323,337,347,365,370,447$. 
proboszczowie biegoniccy byli jej kanonikami, a niektórzy pełnili urząd proboszczowski w zastępstwie za kanonika posiadającego wiele beneficjów. Świadomość tego, że parafia była jedną z kanonii, pozwala tłumaczyć stosunkowo częste zmiany proboszczów oraz różne nieporozumienia związane z przypisywaniem urzędu proboszcza duchownym, którzy nie pełnili tej funkcji. Przedstawienie sylwetek proboszczów ukazuje także wpływ konkretnych duszpasterzy na parafię i parafian (szerzenie kultu świętych, podejście do patriotyzmu).

Opracowanie wpisuje się w poznawanie niemalże 750-letniej historii parafii św. Wawrzyńca w Biegonicach, przygotowującej się do obchodzenia jubileuszu istnienia.

\section{Bibliografia}

\section{Materiały archiwalne}

Archiwum Diecezji Tarnowskiej (ADT).

Archiwum Kurii Metropolitalnej w Krakowie (AKMK).

Archiwum Parafii w Biegonicach (А PB).

Archiwum Parafii św. Małgorzaty w Nowym Sączu (APNs).

\section{Pozostałe źródła i opracowania}

Baczkowska W., Pałaszowski Kazimierz Stanisław, w: Polski słownik biograficzny, t. 25, Kraków 1980, s. 203-204.

Bazielich W., Materiały do historii szpitala, kościoła i prepozytury św. Krzyża w Starym Sączu, „Nasza Przeszłość” 14 (1961), s. 203-247.

Bazielich W., Parafialni proboszczowie starosądeccy, „Nasza Przeszłość” 9 (1959), s. $90-155$.

Biel R., Wczoraj i dziś Kapituły kolegiackiej w Nowym Sązu, Tarnów 2009.

Bieniarzówna J., Janidło Jakub, w: Polski słownik biograficzny, t. 10, Kraków 19621964, S. 512.

Długosz J., Liber Beneficiorum Dioecesis Cracoviensis, t. 1, Kraków 1863.

Fyda S., Kronika Ochotniczej Straży Pożarnej w Biegonicach (rkps).

Herzig F., Katedra, niegdyś kolegiata w Tarnowie, Tarnów 1900.

Kracik J., Kontrreformacja i katolicka reforma, w: Dzieje miasta Nowego Sacza, t. 1, red. F. Kiryk, Warszawa-Kraków 1992, s. 411-433. 
Kumor B., Archidiakonat Sądecki, opracowanie materiałów źródłowych do atlasu historycznego Kościoła w Polsce, „Archiwa, Biblioteki i Muzea Kościelne” 8-9 (1964), s. 93-286.

Kumor B., Dzieje diecezji krakowskiej do roku 1795, t. 3, Kraków 2000.

Kumor B., Ustrój i organizacja Kościoła polskiego w okresie niewoli narodowej 1772-1918, Kraków 1980.

Lachs J., Awedyk Michał, w: Polski słownik biograficzny, t. 1, Kraków 1935, s. 190. Łętowski L., Katalog biskupów, prałatów i kanoników krakowskich, t. 4, Kraków 1853. Murawiec W., Awedyk Michał, w: Słownik polskich teologów katolickich, t. 1, red. H. Wyczawski, Warszawa 1981, s. 80-81.

Natoński B., Pałaszowski Kazimierz, w: Słownik polskich teologów katolickich, t. 3, red. H. Wyczawski, Warszawa 1982, s. 294-296.

Nowak A., Słownik biograficzny kapłanów Diecezji Tarnowskiej 1786-1985, t. 3: K-P, Tarnów 2001.

Salaterski S., Katalog prałatów i kanoników kapituły św. Małgorzaty P.M. w Nowym

Saczu (1448-1791), „Nasza Przeszłość” 8o (1993), s. 169-224.

Salaterski S., Kolegiata i kapituła św. Małgorzaty P.M. w Nowym Sączu (1448-1791), Tarnów 1997.

Sygański J., Historya Nowego Sącza, t. 3: Zabytki dziejowe miasta, Lwów 1902. Sygański J., Nowy Sącz, jego dzieje i pamiątki dziejowe: szkic historyczny, Nowy Sącz 2011.

Szymański J., Kapituła kolegiacka w Wojniczu 1465-1786, Lublin 1962.

\section{Streszczenie}

Artykuł przedstawia sylwetki duchownych, którzy pełnili funkcję proboszczów w parafii św. Wawrzyńca w Biegonicach. Ramy czasowe określają lata istnienia kapituły św. Małgorzaty w Nowym Sączu (1448-1791). Parafia w Biegonicach została jedną z kanonii wspomnianej kapituły, dlatego urząd proboszcza związany był z godnością kanonicką, chociaż były od tego wyjątki. Opracowanie ma na celu przedstawić sylwetki proboszczów, ale także ukazać ich wpływ na parafialne duszpasterstwo, które w głównej mierze zależy od proboszcza - pasterza konkretnej parafii.

\section{Słowa kluczowe}

Biegonice, Nowy Sącz, Sądecczyzna, kapituła kolegiacka, proboszczowie, kanonicy 


\section{Summary}

\section{Pastors of Prebend in Biegonice}

The article presents priest who were pastors in the parish of St. Lawrence in Biegonice. The time range of description is determined by years of existence of the Collegiate of Saint. Margaret in Nowy Sącz (1448-1791). Parish in Biegonice became one of prebends this Collegiate and office of the pastor was associated with canonical dignity, but there were exceptions. The article aims to present profiles of pastors, but also to show their influence on parish pastoral ministry, which mainly depends on the pastor - shepherd of a particular parish.

\section{Keywords}

Biegonice, Nowy Sącz, Collegiate of canons, pastors, canon 